\title{
Paraoxonase-1 Deficiency does not Influence Clopidogrel Antiplatelet Function in Mice
}

\section{Anabel García-Heredia, Anna Hérnandez-Aguilera, Isabel Fort-Gallifa, Jorge Joven, Vicente Martín-Paredero and Jordi Camps*}

Unitat de Recerca Biomèdica (AGH, AHA, IFG, JJ, JC), Hospital Universitari de Sant Joan and the Service of Angiology, Vascular Surgery and Endosurgery, Hospital Universitari Joan XXIII (VMP), Institut d'Investigació Sanitària Pere Virgili (IISPV), Universitat Rovira $i$ Virgili, Spain

\begin{abstract}
Background: Clopidogrel is an antiplatelet agent used in the treatment of vascular diseases. It requires in vivo bio activation linked to the cytochrome P450. Several studies reported that paraoxonase-1 (PON1) was a crucial enzyme in clopidogrel activation, and that patients carrying a variant of the PON1192 gene polymorphism have a high risk of thrombosis. However, these reports were not confirmed by subsequent results. The present study was aimed at investigating whether PON1 deficiency affects the biological action of clopidogrel in mice.
\end{abstract}

Methods: PON1-deficient mice $(n=50)$ and wild type animals $(n=50)$ received different treatments for 3 days: a) clopidogrel, b) aspirin, c) cilostazol, d) clopidogrel + aspirin, and e) clopidogrel + aspirin + cilostazol. Blood was collected for the Platelet Function Analysis (PFA-100).

Results: The different anticoagulant treatments resulted in higher aggregation times in all the mice, compared to the internal PFA control; demonstrating the anti-platelet effect of these compounds. We did not observe any significant alterations on the PFA assay in PON1-deficient mice, relative to wild type animals.

Conclusion: PON1 deficiency does not influence the antiplatelet action of clopidogrel in mice, and supports the proposition that this enzyme is not involved in clopidogrel bio activation.

Keywords: Antiplatelet agents; Clopidogrel; Paraoxonase-1; Vascular diseases

\section{Abbreviations}

ADP: Adenosine Diphosphate; CYP: Cytochrome; PFA: Platelet Function Analysis; PON1: Paraoxonase-1

\section{Introduction}

Clopidogrel is an oral, thienopyridide-class, antiplatelet agent used in the treatment of vascular diseases, including peripheral vascular disease [1]. This compound is a pro-drug that requires enzymatic biotransformation into the active thiol metabolite to facilitate its action of inhibiting platelet adenosine diphosphate (ADP) P2Y12 receptor [2] .Early studies described in vivo bio activation of clopidogrel as a two-step process closely linked to the cytochrome P450 (CYP) 2C19 enzyme [3]. However, Bouman et al. [4] reported that paraoxonase-1 (PON1) was a crucial enzyme in clopidogrel metabolic activation, especially in the second-step. Their article described the first step as an oxidation of clopidogrel to 2-oxo-clopidogrel catalyzed by cytochromes, and the second step as a hydrolytic cleavage (catalyzed by PON1) of the $\gamma$-thiobutyrolactone ring of 2-oxo-clopidogrel to the pharmacologically-active thiol metabolite. They also highlighted that individuals carrying the QQ isoform of $P O N 1_{192}$ gene polymorphism have a higher risk of stent thrombosis. Tselepis et al. [5] showed an inverse association between PON-1 activity and platelet activation following clopidogrel administration, and suggested that PON-1 is an important determinant of clopidogrel antiplatelet efficacy in these patients. Dansette et al. [6] reported that PON1 catalyzes the formation of a minor thiol metabolite, while the biosynthesis of the major clopidogrel metabolite is CYP P450 dependent. These reports generated considerable controversy, and methodological concerns regarding the Bouman et al. article have been published [7]. Subsequent studies failed to show any influence of serum PON1 activity or genetic polymorphisms on clopidogrel bio activation [8-12]. Ancrenaz et al. [12] reported that CYP2C19, CYP2B6 and CYP3A were the most important determinants in the bio activation of clopidogrel in vitro, and a retrospective study by Ohmori et al. [10] did not find any significant association between $P O N 1_{192}$ polymorphism and clopidogrel response in patients who had a myocardial infarction. The present study, conducted in mice, was aimed at investigating whether PON1 deficiency affects the biological action of clopidogrel.

\section{Materials and Methods}

The study adhered to rules for the protection of animals in research, and was approved by the Committee for Animal Experimentation of the Universitat Rovira $i$ Virgili. Genetically modified PON1-deficient mice $(\mathrm{n}=50)$ and wild type animals $(\mathrm{n}=50)$ received an atherogenic diet for 24 weeks. The last 3 days before their sacrifice, they were subdivided into 5 groups to receive different treatments: Group I: clopidogrel [22 mg/kg/day]; Group II: aspirin [60 mg/kg/day]; Group III: cilostazol [50 mg/kg/day]; Group IV: clopidogrel + aspirin; Group V: clopidogrel + aspirin + cilostazol. All treatments were administered by oral gavage. These drugs, alone or in combination, are currently used for the treatment of coagulation disorders in patients with PAD $[13,14]$. Cilostazol is a phosphodiesterase inhibitor with antiplatelet properties which plays an important role in thrombosis prevention [14]. PON1-deficient animals of the C57BL/6J genetic background

*Corresponding author: Jordi Camps, Unitat de Recerca Biomèdica, Hospital Universitari de Sant Joan, C/ Sant Joan s/n, 43201 Reus, Spain, Tel: +34 977310 300; E-mail: jcamps@grupsagessa.com

Received June 15, 2015; Accepted July 06, 2015; Published July 12, 2015

Citation: García-Heredia A, Hérnandez-Aguilera A, Fort-Gallifa I, Joven J, Camps J, et al. (2015) Paraoxonase-1 Deficiency does not Influence Clopidogrel Antiplatelet Function in Mice. Cardiol Pharmacol 4: 148. doi:10.4172/23296607.1000148

Copyright: (c) 2015 Garcia-Heredia A. This is an open-access article distributed under the terms of the Creative Commons Attribution License, which permits unrestricted use, distribution, and reproduction in any medium, provided the original author and source are credited. 
were the progeny of mice provided by the Division of Cardiology of the University of California in Los Angeles [15]. Wild-type animals were from the C57BL/6J strain (Charles River Labs., Wilmington, MA, USA). Mice were bled by cardiac puncture and all the blood obtained (about $2 \mathrm{~mL}$ ) was collected into citrate-containing tubes for the Platelet Function Analysis (PFA-100). This is an in vitro method that replicates the platelet aggregation process. Using a membrane coated with collagen which promotes platelet adhesion, the membranes are covered with either epinephrine or ADP to promote platelet activation. The PFA is a functional assay, and samples are interpreted as having an inhibited coagulation when the measured coagulation times are higher than those of the internal controls (control collagen/epinephrine: 113137 seconds; control collagen/ADP: 87-105 seconds). The high volume of sample required to perform this technique precluded other analytical determinations being performed in serum.

To ensure that genetically modified mice were really PON1deficient, we measured PON1 lactonase activity in excised liver homogenates, since the liver is a key organ for clopidogrel activation as well as PON1 synthesis $[1,16]$. For this purpose $30 \mathrm{mg}$ of liver were homogenized in $500 \mu \mathrm{l}$ of a $25 \mathrm{mM}$ Tris- $\mathrm{HCl}$ buffer $(\mathrm{pH}=7.4)$ containing $100 \mathrm{mM} \mathrm{NaCl}$, and 1\% Nonidet-40, and using a Precellys 24 homogenizer (Bertin Technologies, France).

\section{Results and Discussion}

The different treatments produced higher aggregation times in all the mice, compared to the internal PFA control and, as such, demonstrating the anti-platelet effect of these compounds against collagen-induced platelet aggregation. We did not observe any significant alteration in the PFA assay in PON1-deficient mice, relative to wild type animals (Table 1). In addition, hepatic PON1 activity was measurable only in wild type mice, but not in PON-1 deficient animals.

PFA has been developed as a standard test for the detection of dysfunction within the platelet adhesion and aggregation pathways. One of the most common reasons for PFA prolongation is the administration of platelet anti-aggregants [17-19]. Collagen, epinephrine and ADP, under in vivo physiological conditions, promote substances facilitating adhesion and aggregation of platelets. This assay has been studied and validated in rats and mice, and closure times in

\begin{tabular}{|c|c|c|c|}
\hline Group & Parameters & Wild type & $\begin{array}{c}\text { PON-1 } \\
\text { deficient }\end{array}$ \\
\hline \multirow{3}{*}{ I: Clopidogrel $(n=10)$} & Collagen/EPI (seconds) & $>300$ & $>300$ \\
\hline & Collagen/ADP (seconds) & $>300$ & $156->300$ \\
\hline & PON1 activity (mU/g) & $7.8(1.5)$ & $<\mathrm{DL}$ \\
\hline \multirow{3}{*}{ II: Aspirin $(n=10)$} & Collagen/EPI (seconds) & $>300$ & $>300$ \\
\hline & Collagen/ADP (seconds) & $>300$ & $>249$ \\
\hline & PON1 activity (mU/g) & $11.5(5.4)$ & $<\mathrm{DL}$ \\
\hline \multirow{3}{*}{ III: Cilostazol $(n=10)$} & Collagen/EPI (seconds) & $>300$ & $>300$ \\
\hline & Collagen/ADP (seconds) & $>300$ & $>300$ \\
\hline & PON1 activity (mU/g) & $15.8(6.6)$ & $<\mathrm{DL}$ \\
\hline \multirow{3}{*}{$\begin{array}{l}\text { IV: Clopidogrel + Aspirin } \\
\quad(n=10)\end{array}$} & Collagen/EPI (seconds) & $>300$ & $>300$ \\
\hline & Collagen/ADP (seconds) & $>300$ & $>249$ \\
\hline & PON1 activity (mU/g) & $13.3(4.7)$ & $<\mathrm{DL}$ \\
\hline \multirow{3}{*}{$\begin{array}{l}\text { V: Clopidogrel + Aspirin } \\
\quad+\text { Cilostazol }(n=10)\end{array}$} & Collagen/EPI (seconds) & $>300$ & $>300$ \\
\hline & Collagen/ADP (seconds) & $>300$ & $>300$ \\
\hline & PON1 activity (mU/g) & $8.6(1.3)$ & $<\mathrm{DL}$ \\
\hline
\end{tabular}

< DL: below detection limit, Values are expressed as means with standard deviations in parentheses.

Table 1: Plasma PFA assay and hepatic PON1 activity in the groups of experimental mice. control animals are approximately 100 seconds [20]. Our results show that PON1 deficiency does not produce any significant alteration in the anticoagulant function of the tested drugs. These results support, and extend, recent findings in humans. Sibbing et al. [21] analyzed the ADP-induced platelet aggregation in relation to $P O N 1_{192}$ and $C Y P 2 C 19$ gene polymorphisms in patients following a coronary stent insertion. The results showed that the $P O N 1_{192}$ polymorphism did not influence platelet response to clopidogrel nor the risk of thrombosis in these patients. The CYP2C19 polymorphism, however, had an impact on the antiplatelet effect of clopidogrel and on thrombosis risk. Further, the results of a systematic review and meta-analysis from Reny JL et al. [22] did not support $P O N 1_{192}$ genotype as a major determinant of the biological response to clopidogrel, nor as a risk-factor for major cardiovascular ischemic events in clopidogrel-treated patients.

\section{Conclusion}

We conclude that PON1 deficiency does not influence the antiplatelet action of clopidogrel in mice, thus supporting the proposition that this enzyme is not involved in its bio activation.

\section{Acknowledgments}

Editorial assistance was provided by Dr. Peter R. Turner of Tscimed.com. This study was supported by a grant from the Instituto de Salud Carlos III (PI1102817), Madrid, Spain.

\section{Conflicts of Interest}

The authors report no conflicts of interest.

\section{References}

1. Wang $X Q$, Shen $C L$, Wang $B N$, Huang $X H$, Hu ZL, et al. (2014) Genetic polymorphisms of CYP2C $19^{*} 2$ and ABCB1 C3435T affect the pharmacokinetic and pharmacodynamics responses to clopidogrel in 401 patients with acute coronary syndrome. Gene 558: 200-207.

2. Smith SC Jr, Feldman TE, Hirshfeld JW Jr, Jacobs AK, Kern MJ, et al (2006) ACC/AHA/SCAI 2005 Guideline Update for Percutaneous Coronary Intervention-Summary Article: A Report of the American College of Cardiology/ American Heart Association Task Force on Practice Guidelines (ACC/AHA) SCAI Writing Committee to Update the 2001 Guidelines for Percutaneous Coronary Intervention). J Am Coll Cardiol 47: 216-235.

3. Kazui M, Nishiya Y, Ishizuka T, Hagihara K, Farid NA, et al. (2010) Identification of the human cytochrome P450 enzymes involved in the two oxidative steps in the bio activation of clopidogrel to its pharmacologically active metabolite. Drug Metab Dispos 38: 92-99.

4. Bouman HJ, Schömig E, van Werkum JW, Velder J, Hackeng CM, et al. (2011) Paraoxonase- 1 is a major determinant of clopidogrel efficacy. Nat Med 17: 110 116.

5. Tselepis AD, Tsoumani ME, Kalantzi KI, Dimitriou AA, Tellis CC, et al. (2011) Influence of high-density lipoprotein and paraoxonase-1 on platelet reactivity in patients with acute coronary syndromes receiving clopidogrel therapy. J Thromb Haemost 9: 2371-2378.

6. Dansette PM, Rosi J, Bertho G, Mansuy D (2012) Cytochromes P450 catalyze both steps of the major pathway of clopidogrel bioactivation, whereas paraoxonase catalyzes the formation of a minor thiol metabolite isomer. Chem Res Toxicol 25: 348-356.

7. Camps J, Joven J, Mackness B, Mackness M, Tawfik D (2011) Paraoxonase-1 and clopidogrel efficacy. Nat Med 17: 1041-1042.

8. Gong IY, Crown N, Suen CM, Schwarz UI, Dresser GK, et al. (2012) Clarifying the importance of CYP2C19 and PON1 in the mechanism of clopidogrel bio activation and in vivo antiplatelet response. Eur Heart J 33: 2856-2464a.

9. Hulot JS, Collet JP, Cayla G, Silvain J, Allanic F, et al. (2011) CYP2C19 but not PON1 genetic variants influence clopidogrel pharmacokinetics, pharmacodynamics, and clinical efficacy in post-myocardial infarction patients Circ Cardiovasc Interv 4: 422-428.

10. Ohmori T, Yano Y, Sakata A, Ikemoto T, Shimpo M, et al. (2012) Lack of association between serum paraoxonase-1 activity and residual platelet aggregation during dual anti-platelet therapy. Thromb Res 129: e36-e40. 
Citation: García-Heredia A, Hérnandez-Aguilera A, Fort-Gallifa I, Joven J, Camps J, et al. (2015) Paraoxonase-1 Deficiency does not Influence Clopidogrel Antiplatelet Function in Mice. Cardiol Pharmacol 4: 148. doi:10.4172/2329-6607.1000148

11. Delaney JT, Ramirez AH, Bowton E, Pulley JM, Basford MA, et al. (2012) Predicting clopidogrel response using DNA samples linked to an electronic health record. Clin Pharmacol Ther 91: 257-263.

12. Ancrenaz V, Desmeules J, James R, Fontana P, Reny JL, et al. (2012) The paraoxonase-1 pathway is not a major bio activation pathway of clopidogrel in vitro. Br J Pharmaco I166: 2362-2370.

13. Whayne TF (2012) A review of the role of anticoagulation in the treatment of peripheral arterial disease. Int J Angiol 21: 187-194.

14. Lee SW, Park SW, Kim YH, Yun SC, Park DW, et al. (2011) A randomized, double-blind, multicenter comparison study of triple antiplatelet therapy with dual antiplatelet therapy to reduce restenosis after drug-eluting stent implantation in long coronary lesions: results from the DECLARE-LONG II (Drug-Eluting Stenting Followed by Cilostazol Treatment Reduces Late Restenosis in Patients with Long Coronary Lesions) trial. J Am Coll Cardiol 57: $1264-1270$

15. Shih DM, Gu L, Xia YR, Navab M, Li WF, et al. (1998) Mice lacking serum paraoxonase are susceptible to organophosphate toxicity and atherosclerosis. Nature 394: 284-287

16. Camps J, Marsillach J, Joven J (2009) The paraoxonases: role in human diseases and methodological difficulties in measurement. Crit Rev Clin Lab Sci 46: 83-106.
17. Quiroga T, Goycoolea M, Muñoz B, Morales M, Aranda E, et al. (2004) Template bleeding time and PFA- 100 have low sensitivity to screen patients with hereditary mucocutaneous hemorrhages: comparative study in 148 patients. J Thromb Haemost 2: 892-898.

18. Posan E, McBane RD, Grill DE, Motsko CL, Nichols WL (2003) Comparison of PFA-100 testing and bleeding time for detecting platelet hypo function and von Willebrand disease in clinical practice. J Thromb Haemost 90: 483-490.

19. Hayward CP, Harrison P, Cattaneo M, Ortel TL, Rao AK (2006) Platelet Physiology Subcommittee of the Scientific and Standardization Committee of the International Society on Thrombosis and Haemostasis. Platelet function analyzer (PFA)-100 closure time in the evaluation of platelet disorders and platelet function. J Thromb Haemost 4: 312-319.

20. Kim CW, Yun JW, Bae IH, Park YH, Jeong YS, et al. (2011) Evaluation of antiplatelet and anti-thrombotic effects of cilostazol with PFA-100® and Multiplate $\AA$ whole blood aggregometer in vitro, ex vivo and $\mathrm{FeCl} 3$-induced thrombosis models in vivo. Thromb Res 127: 565-570.

21. Sibbing D, Koch W, Massberg S, Byrne RA, Mehilli J, et al. (2011) No association of paraoxonase-1 Q192R genotypes with platelet response to clopidogrel and risk of stent thrombosis after coronary stenting. Eur Heart $J$ 32: $1605-1613$.

22. Reny JL, Combescure C, Daali Y, Fontana P (2012) Influence of the paraoxonase-1 Q192R genetic variant on clopidogrel responsiveness and recurrent cardiovascular events: a systematic review and meta-analysis. J Thromb Haemost 10: 1242-1251. 